\title{
Participative democracy or party/race consolidation
}

\section{Bishnu Ragoonath}

\section{(2) OpenEdition}

\section{Journals}

Édition électronique

URL : http://journals.openedition.org/plc/513

DOI : $10.4000 /$ plc. 513

ISSN : 2117-5209

Éditeur

L'Harmattan

\section{Édition imprimée}

Date de publication : 1 janvier 1999

Pagination : 199-225

ISSN : 1279-8657

\section{Référence électronique}

Bishnu Ragoonath, «Participative democracy or party/race consolidation », Pouvoirs dans la Caraïbe [En ligne], 11 | 1999, mis en ligne le 07 mars 2011, consulté le 30 avril 2019. URL : http:// journals.openedition.org/plc/513; DOI : 10.4000/plc.513 


\section{Participative democracy or party/race consolidation}

by Bishnu RAGOONATH University of the West Indies St Augustine

Trinidad and Tobago

\section{The structure and philosophy of Trinidad's local government}

With just under forty-four (44) per cent of the electorate participating in the 1996 local government poll ${ }^{1}$, questions have been raised regarding the structure, functions and importance of local government to the citizenry at large. To be sure, it has been suggested that with the turnout at the local government poll being substantially lower than the turnout at Parliamentary elections ${ }^{2}$, the lower voter participation is reflective of the apathy which the vast majority of the citizenry has for local government. Of course such apathy could be interpreted as a direct result of the fact that many people remain

1. The exact turnout at the polls was $43,82 \%$ of the electorate. See Trinidad and Tobago, Elections and Boundaries Commission, «Report of the Elections and Boundaries Commission on the Local Government Elections Held on Monday, June 24, $1996 »$, Port of Spain, 1996.

2. In the Parliamentary elections of 1986, 1991 and 1995, the percentage of votes cast against the electorate was $65,45 \%, 65,76 \%$ and $63,30 \%$ respectively. See Trinidad and Tobago, Elections and Boundaries Commission, « Report of the Elections and Boundaries Commission on the Parliamentary Elections Held on Monday November 6, 1995 », Port of Spain, 1996, Appendix 8, p. 270. 
uninformed about the structure and functions of local government authorities $^{3}$. Such lack of knowledge or even the general apathy towards local government could be explained by the history, and more particularly the more recent history, of local government in Trinidad.

Although the notion of local government had its origins, in Trinidad, from as early as the $16^{\text {th }}$ century, when the island was under Spanish colonial rule, the modern concept of local government is a far cry from what existed under colonial rule. Contemporary local government authorities, in Trinidad, have very limited powers and functions when compared with the powers which the Cabildo exercised under Spanish colonial rule, and even under the Town councils system as was instituted under British colonialism ${ }^{4}$. To be sure, the present system of local government only affords four (4) of the fourteen (14) local government authorities the power to raise revenues. Put differently, ten (10) local government authorities do not have the power to collect rates and taxes 5 . Moreover, in the cases of the four municipal authorities which are allowed, in law, to raise revenues from land and building taxes, as well as other charges, the revenues raised accounts for between 5 percent and 20 percent of expenditure ${ }^{6}$.

3. For empirical data on the ordinary citizens appreciation of local government in Trinidad, see Bishnu Ragoonath, Decentralization. Local Government and Development : Trinidad, 1952-1990, (Unpublished Ph.D. Thesis), The University of the West Indies, 1991.

4. For an extended discussion on the role and functions of local government authorities under Spanish and British colonial administrations, see B. Ragoonath, «Shifting Nature of Decentralization: A Review of the Evolution of Local Government in Trinidad and Tobago », in Indian Journal of Public Adrninistration, Vol. 39, n 4, 1993.

5. It may be noted that the legislation governing Local Government in Trinidad, namely the Municipal Corporations Act - Act 21 of 1990, makes provision for all corporations to raise revenues and collect taxes. However, specific sections of the Act were not Assented to, by the President, and thus created the division whereby the older Cities, town and Borough councils were allowed to collect such taxes, but not the Regional Corporations. It may also be noted that the UNC-NAR government caused those sections of the Act which were not previously Assented, to get the Assent from the President, a mere week before the 1996 poll.

6. See B. Ragoonath, «Trends in Commonwealth Caribbean Local Government Part II : The Trinidad Case », in Local Government World, $\mathrm{n}^{\circ}$ 6, December 1995, 
Effectively, therefore, local governments, in Trinidad, remain dependent upon central government for the majority of their funding. Such funding, it may be instructive to note, is normally inadequate resulting in inefficiencies and ineffective delivery of services provided by local governments.

The controls exercised by the central government with respect to finance inevitably impacts upon the functions and operations of the local government authorities. Local authorities, in Trinidad, are required to maintain roadways, drainage, markets, parks and recreation grounds, cemeteries and public buildings. However, they are not involved in the provision of public utilities such as water, electricity, and fire prevention nor do they play any integral role in transportation, ports control or management, and education. Moreover, central government's permission is required, through the minister's consent, before any local authority embarks upon the erection or acquisition of buildings to establish libraries, or to care for infants and/or indigent persons or even «generally for the improvement of the Municipality and for the benefit of the inhabitants thereof $»^{7}$. In such a situation, Trinidad's local governments are largely impotent with limited powers and autonomy. Consequently, in the run up to the 1996 elections, the issue of power and authority of local government was to become a major campaign issue, with all the political parties advocating greater devolution and empowerment. This paper will elaborate on this and other campaign issues later. However, as stated above, based on it limited financial base, as well as the limited role local authorities were allowed to play in the development of their communities, local government has been and continues to be viewed as of little importance in the society.

The limitations with respect to functions and finances were not the only reasons for local government to be viewed in a negative context, for the central government in Trinidad has also played a direct

pp. 10-11. See also Ragoonath, Decentralization. Local Government and Development : Trinidad. 1952-1990.

7. Trinidad and Tobago, Parliament, «Municipal Corporations Act ( $n^{\circ} 21$ of 1990) », Port of Spain, 1990, Section 112 (2) d. 
role in emasculating local government. To be sure, local government authorities operated as mere agents of central government in administering various functions, but without any real authority in developing community participation and development ${ }^{8}$. Such deficiencies were further compounded in the post 1973 period, when, with the country having benefitted from an oil boom, the central government usurped various functions which local governments were legally authorized to perform. Central government by-passed local government councils and directly involved itself in providing recreation and market facilities. Furthermore, state owned companies were established for the repair of roads and to provide sanitation services, thereby duplicating the service providers, and which, by extension, emphasized the helplessness of the local authorities which were starved for funds ${ }^{9}$. The effect of all of this was the further loss of confidence of the electorate towards local government, the result of which was low voter turnout at the polls.

But whereas it could and has been suggested that voter participation at the polls in the 1996 local government elections was low, it may be noted that when compared with other local government elections, the 1996 turnout has been the highest ever recorded. Prior to 1996, the turnout at local government elections never exceeded 40 percent of the electorate, the previous highest turnout was in 1987, when 39,9 percent of voters participated ${ }^{10}$. This higher than normal local government turnout in 1996 can partially be explained on the basis of national politics in Trinidad. In this regard, it may be noted that national politics in Trinidad is dominated by party politics as well as race and ethnicity-based politics.

8. For a discussion of the emasculation of local government from a community development perspective, see S. Craig, Community Development in Trinidad and Tobago : From Welfare to Patronage, Jamaica, ISER, 1974.

9. See Bishnu Ragoonath, «Decentralization and Structural Adjustment: An Analysis of the Impact of Structural Adjustment to the Decentralization Process in Trinidad and Tobago », in J. La Guerre ed., Structural Adjustment : Public Policy and Administration in the Caribbean, Trinidad, School of Continuing Studies, UWI, 1994.

10. See Trinidad and Tobago, Elections and Boundaries Commission, « Report of the elections and Boundaries Commission on the Local Government Elections Held on Monday 28 September, $1992 »$, Port of Spain, 1992, Appendix VII(b). 


\section{PARTY POLITICS IN A PLURAL SOCIETY}

Trinidad is sometimes described as an «institutionally plural society $\gg^{11}$ bordering on being an ethnically bipolar society ${ }^{12}$. Bipolar societies are those wherein there are two major ethnic blocs, approximately equal in size and which together constitute eighty percent or more of the population ${ }^{13}$. Trinidad falls short of being bipolar since the total of both blocs is just 79,86 percent of the national population. Notwithstanding this shortcoming in bipolar analysis, it may be noted that the Afro-Trinidadian bloc (39,6 percent) and the Indo-Trinidadian bloc $(40,26 \text { percent })^{14}$, are of near equal strength in terms of numbers. The fact that both groups have tended to compete for political power over the years, and which culminated in a tie at the 1995 Parliamentary elections and with a very close result in the 1996 local government poll, emphasizes the bipolarity of the society. Such results however are better explained through the plural society theory.

The plural society thesis takes its point of departure from the perspective of two groups living side by side, and only meet in the marketplace ${ }^{15}$. Based on the history of both major groups, in Trinidad, this is generally what obtains. The Afro-Trinidadian group are the descendants of African slaves who were brought to Trinidad, under British colonialism, to work on the sugar estates. With the end of slavery, the Africans left the plantations, thereby creating a demand for new labor. East Indians were then brought as indentured laborers to fill the labor void, on the sugar estates. Based on such a history, IndoTrinidadians have tended to remain closer to the areas where sugar cane is still being cultivated, or was cultivated in the time of

11. See M. G. Smith, «Pluralism and Social Stratification », in Ryan S. ed., Social and Occupational Stratification in Contemporary Trinidad and Tobago, Trinidad, Institute of Social and Economic Research, UWI, 1991.

12. See R. S. Milne, Politics in Ethnically Bipolar states, Vancouver, UBC, 1981.

13. See Milne, Politics in Ethnically Bipolar States, p. 1.

14. See Population data from the 1990 Census, as is found in Trinidad and Tobago, Central Statistical Office, « Annual Statistical Digest 1992 », Port of Spain, 1995.

15. For a general discussion of the tenets of the plural society as it relates to Trinidad, see Smith, Pluralism and Social Stratification. Also see M. G. Smith, Culture. Race and Class in the Commonwealth Caribbean, Jamaica, UWI, 1984. 
indentureship $^{16}$. Based on their location and settlement, IndoTrinidadians continue to dominate the agricultural sector or have moved into private businesses, again predominantly located on the plains in central and south Trinidad, in close proximity to the former sugar cane estate areas. Afro-Trinidadians, on the other hand, are today predominately found living in the urban areas in the north of the island, as well as close to the petroleum industrial sites in the south. Based on their locale, Afro-Trinidadians dominate public sector jobs ${ }^{17}$ as well as having a heavy presence in the industrial sector and more particularly the petroleum industry. Effectively, this racial separation in terms of demography and occupation facilitates the adoption of a plural society thesis for Trinidad, but more importantly, it promotes political separatism, which would impact on the democratic process and elections. Before implications on the politics are developed, it may be instructive to note one other aspect of the plural society thesis which has implications for political behavior in Trinidad, and this relates to culture and religion.

Apart from demography and occupation, cultural behavior and traditions, as well as religious practices, also accentuate differences and separation between the races in Trinidad. With regard to the AfroTrinidadian community, when the African slaves were brought over, they were denied the opportunity to retain and practice aspects of African culture and was thus forced to assimilate Western culture and Christianity. The result of this is that the majority of Afro-Trinidadians today engage in Western cultural behavior and traditions as well as practice Christianity. The lndo-Trinidadian community, on the other hand, have been able to retain cultural traditions as well religious

16. See Colin Clarke, «Spatial pattern and Social Interaction among Creoles and Indians in Trinidad and Tobago », in Yelvington K. ed., Trinidad Ethnicity, Tennessee, The University of Tennessee Press, 1993.

17. Statistics show that Indo-Trinidadians account for $34 \%$ of Public service jobs, $24 \%$ of police Service positions and $10 \%$ of the military. See L. L. Dattoo, «Ethnic Conflict Resolution in Trinidad and Tobago: The Role of Proportionality in Representative Bureaucracy », Journal of Ethno-Development, Vol. 3, n 3, 1994. See also S. Ryan and J. La Guerre, Employment Practices in the Public and Private Sectors in Trinidad and Tobago, St. Augustine, Centre for Ethnic Studies, 1993. 
beliefs as were practiced by their indentured East Indians forefathers. Consequently, a substantial section of the Indo-Trinidadian community presently engage in Indian cultural traditions with regard to food, music, dance and even dress. With regard to religion about 60 percent of Indo-Trinidadians are Hindu, while just over 10 percent are Muslim $^{18}$. The notion of religion and culture is critical to Trinidad's politics, especially since it was only in 1995 that a non-Christian government took office. Before exploring the politics which led to such a political outcome, it must be emphasized that all separation between the two major races, as indicated above, are generalized. Put differently, there is no exclusivity of any one race in any area of activity or even settlement. Thus, it is near impossible to find a community in Trinidad inhabited solely by persons of one race. Similarly, there is no occupational form which is exclusive to one group, devoid of persons of another race.

Based on the demography, occupation, cultural behavior and religion, politics in Trinidad have incurred some separation. IndoTrinidadians have traditionally supported the political party connected with the sugar workers union and which was led by an IndoTrinidadian. It may be noted that since 1956, when «party politics » took firm root, with racial connotations ${ }^{19}$, the «Indian Party » has undergone various metamorphosis and name changes, culminating in what is presently known as the United National Congress (UNC) ${ }^{20}$. The Afro-Trinidadian party has been much more stable and has been able to maintain a single party structure, in the form of the People's National Movement (PNM), since 1956. This party is led by an AfroTrinidadian, and has traditionally had the support of the Waterfront workers union, as well as public sector and other urban-based trade unions. But, while such distinctions can be made with reference to the

18. See Trinidad and Tobago, Central Statistical Office, «Annual Statistical Digest ».

19. See S. Ryan, Race and Nationalism in Trinidad and Tobago, Toronto, University of Toronto Press, 1972.

20. For a discussion on the evolution of the various «Indian Parties » see B. Ragoonath, « Race and Class in Caribbean Politics », in Plural Societies, Vol. 18, $n^{\circ} 1$, 1988. 
generalized political behavior of the two major racial blocs, it must be emphasized that such descriptions are generalizations, and it is not unusual to find Indo-Trinidadians supporting the PNM and AfroTrinidadians supporting the UNC. Effectively, there is no mutual exclusivity in terms of political participation and behavior. Notwithstanding this, the fact remains that supporters of either party are predominantly of the same race as that of the leader of the party.

The fact that two parties, representing the two major racial blocs, presently dominate the political scene in Trinidad, should not be used to suggest that there are no other parties. To be sure, various other parties have developed over the years and some are still existent until today. These parties tend to try to bridge the racial gap, thereby seeking to present a multiracial party. All but one such party failed to achieve any success at elections. In the one instance that there was success, such success came with United Labour Front, the «Indian Party » at that time, submerging itself with other parties, in 1986, tp form the National Alliance for Reconstruction (NAR) which contested and won the election. However, shortly after its ascension into office, the party split apart with various elements going back to their original form $^{21}$. When the «Indian Party» withdrew and reformatted itself under the banner of the UNC, it was made clear that the NAR's success depended upon the «Indian vote » and without which, it could no longer muster enough support to have any real success in elections. The party failed to win a seat, in Trinidad, in the Parliamentary elections of 1991 and 1995, as well as in the local government elections of 1992 and 1996. Notwithstanding this inability to win in a first past the post system, the party has continuously been able to win substantial levels of support. From this perspective, it is clear that there is a segment of the population in favor of accommodation politics, beyond race-based party politics as currently exists.

21. For an elaborate discussion on the formation and dissolution of the NAR, see S. Ryan, The Disillusioned Electorate, Port of Spain, Imprint, 1989. 


\section{POLITICAL COMPETITION AND ELECTORAL STALEMATES}

In a system based on party politics and more so race-based party politics, it was inevitable that once the two major racial blocs equalized, political competition would become crucial in determining which group would seize political power. Moreover, acknowledging the spatial demography, it was clear that political stalemates would arise. This is exactly what occurred in the 1995 Parliamentary elections and was more or less repeated in the 1996 local government elections.

At the end of september 1995, the term of office of all local government councils expired. The legislation governing Local Government polls in Trinidad provided that elections be held within three months from the date of the expiration of the previous councils, thus the country awaited the Prime Minister announcement of the date for the local government poll. However, on 6 october 1995, when the Prime Minister did go to the Parliament to announce an election date, he surprised the nation by posting 6 november 1996 as the date for Parliamentary elections, rather than the date for the local government poll. Effectively, the Prime Minister dissolved Parliament. It may be instructive to note that the Parliamentary term was due to expire some fourteen months later.

With the country and the political parties having been given a mere one month to campaign for a parliamentary election, and moreso one for which they were not prepared nor expected, the politicking was two-pronged, based on personalities as well as issues. From the perspective of the ruling PNM, the party and its leadership boasted that it had caused a turn around in the economy and that the country was on the road back to economic growth and success. In this scenario, the PNM's campaign slogans included that of bringing the country back to being «World Class $»^{22}$ and boasted of «Leadership that's

22. PNM leader and Prime Minister Patrick Manning told a PNM elections convention that his party was «the only vehicle for making Trinidad and Tobago a world class society ». See «Speech Delivered by Political Leader of the PNM, Prime 
Working ${ }^{23}$. But in promoting its own leadership, the party launched a vicious personality campaign against the opposition leader, Basdeo Panday, and his colleague, Ramesh Lawrence Maharaj. The attack on Panday was based on sexual harassment charges which were before the courts, and which were later thrown out as being without substance. With respect to the attacks on Maharaj, the PNM's leader, Patrick Manning, feared Maharaj, a prominent and successful criminal and human rights attorney, becoming Attorney General. Manning, in his quest to undermine Maharaj's credibility, reminded the population that Maharaj's name was mentioned in the Scott Drug Report, notwithstanding that the report did not demonstrate any wrongdoing, far less to have proven such on Maharaj's part. While there was initial support for Manning, especially in relation to his fear of Maharaj becoming Attorney General ${ }^{24}$, the counter claims by Maharaj and the $\mathrm{UNC}$, in relation to dealing with crime and corruption, led to a swelling of the ranks of the UNC.

Since the UNC was in opposition and did not have a record on which it could boast, it took the challenge of taking the campaign to the PNM. The UNC's campaign seems to have led the debate, with the PNM grasping to react to the UNC's pronouncements. The UNC's campaign focussed on the many issues which were affecting the society, such as crime, poverty, employment and education. The centrepiece of the UNC's campaign was the urgent need for crime prevention and suppression $^{25}$. This was of particular interest to the middle and upper classes, many of whom believed they were targets of criminal activity, and, moreover, with the police being largely immobile, citizens felt they could no longer rely on the police for help. The UNC thus called upon the citizens to « give yourself a chance for

Minister Patrick Manning at the Chaguaramas Convention Centre », Newsday (Trinidad), 10 october 1995, p. 18.

23. See People's National Movement, «People's National Movement Elections 1995 Manifesto », Port of Spain, 1995.

24. See B. C. Pires, «Ah iraid Ramesh », Daily Express (Trinidad), 3 november 1995, p. 8.

25. See The United National Congress, «UNC Manifesto/95 : Plan for Change », Couva, 1995. 
better jobs, a safer community, improved schools and a brighter future ${ }^{26}$. Apart from dealing with the issues, the UNC had the advantage of one other card which both the PNM, as well as history had played into the UNC's hand ; this was the card of race-based, and, more specifically, Indo-Trinidadian politics. From the historical perspective, 1995 marked the $150^{\text {th }}$ anniversary of the arrival of the first Indo-Trinidadians to the island of Trinidad. Accordingly, throughout the year, although climaxing on 30 may 1995, the anniversary date of the arrival of the first shipload of Indians, various activities were staged, all of which sought to engender amongst the Indian community a spirit of arrival and belonging. Such belonging was critical, for prior to 1995, while some Indo-Trinidadians were able to attain some economic power, the community as a whole was never able to wield any real social or political power. In the plural society context, where Afro-Trinidadians dominated the political and social spheres, Indo-Trinidadians had been relegated to being a minority, with the psychological underpinnings of being a minority, subordinate group of second-class citizens ${ }^{27}$. The commemoration of the $150^{\text {th }}$ anniversary sought to change that, and when given a chance later in the year to make a statement of Indo-Trinidadian solidarity, oneness and power, the community voted for the UNC, the Indo-Trinidadian party, to ensure that for the first time in the country's history, an IndoTrinidadian government and Prime Minister would hold office.

It may be instructive to note that for PNM leader, Patrick Manning, a major issue in the election was that there was «a strong desire among certain sections of the community to have and Indian Prime Minister» and hence the «emotive appeals» on this basis ensured a victory for Basdeo Panday ${ }^{28}$.

26. United National Congress, «UNC Manifesto/95 », Couva, 1995, back cover.

27. See S. Ryan, «Beware the Drums of Indian Arrival», in Sunday Express, January 8, 1995, p. 9. Also see B. Tewarie, "Hinduism, Nation-Building and the State », in S. Ryan ed., The Independence Experience 1962-1987, St. Augustine, The Institute of Social and Economic Research, 1988.

28. See V. Baksh, «I have no regrets' Manning Toasts the Best Government T\&T has ever had », in Sunday Guardian (Trinidad), 3 december 1995, p. 5. 
Alongside the historical perspective, Indo-Trinidadian solidarity around the UNC was bolstered by what may be termed an anti-IndoTrinidadian outlook of the PNM. Such an outlook started emerging early in 1995, when the PNM leader and Prime Minister, Patrick Manning, fired his Indo-Trinidadian Minister of Foreign Affairs, Ralph Maraj. The firing of Maraj followed a period during which Maraj openly queried styles of leadership as within the country. While Maraj never indicted the Prime Minister's leadership, it was clear that he was having problems with his political leader. Accordingly, and with a very frivolous explanation, the Prime Minister, in a televised broadcast, publicly fired Maraj. Within months of the firing of Maraj, Manning and the PNM found themselves at odds with Maraj's sister, Occah Seapaul, who was also the Speaker of the House of Representatives. With their razor-thin majority, the PNM could not afford the Speaker to rule against the government. Moreover, when disparaging remarks towards the Speaker were made by senior government Ministers in the House, the Speaker suspended a Minister, and several others were said to be under review. At that moment the Manning administration placed the Speaker under House arrest. These actions by Manning and the PNM were immediately placed in a racial context. With the PNM already being stereotyped as an Afro-Trinidadian party, the Maraj dismissal and Seapaul's arrest further suggested that the party was seemingly purging itself of Indo-Trinidadians. The PNM's actions against Maraj and Seapaul led to Maraj joining the UNC and contesting the elections on behalf of the Indo-Trinidadian Party. Moreover, on mounting the UNC platform, Maraj is reported as having said he had finally come home within the UNC and this was where he belonged $^{29}$, thereby confirming the racial suspicions borne by many Indo-Trinidadians that the PNM was hostile to the Indo-Trinidadian community. The racial divide thus served to galvanize the IndoTrinidadian community to vote against the PNM in 1995.

29. See «Ralph Maraj presents first UNC candidate», in Trinidad Guardian (Trinidad), 7 october 1995, p. 1. 
In such a scenario the Parliamentary elections of 1995 were contested on 6 November 1996. Consequently, based on the race-based demographic map, the UNC was able to win all but one seat where Indo-Trinidadians accounted for over 35 percent of the populace ${ }^{30}$. In terms of numbers, this meant that the UNC was able to capture 17 of the 34 seats available in Trinidad. With the other 17 seats going to the PNM, an electoral tie arose, thereupon leaving the country in a state of indecision, with no one party able to form a government on its own. Fortunately however, there was Tobago ${ }^{31}$, the smaller island in the unitary state of Trinidad and Tobago. In terms of the composition of the House of Representative, Tobago had two seats, which in the 1995 election were won by the candidates of the National Alliance for Reconstruction (NAR). The two elected NAR representatives were not obtuse to the notion of entering into a coalition and this they did with the UNC, thus making it possible for the President to offer the Prime Ministerial position to the UNC leader, Basdeo Panday. A UNC-NAR coalition government was thus installed. The fact that a government was formed meant that the electoral stalemate emanating out of the 1995 Parliamentary election was thus settled. Such a resolution was but a stop-gap measure, since, it became clear that once Trinidadians voted along racial lines, electoral ties, in Trinidad, were almost inevitable. To be sure, it was to recur in the local government election which was held eight months later.

30. For a breakdown of the racial composition of constituencies in Trinidad, see Selwyn Ryan, «Communalism vs. Cosmopolitanism : Indian Responses to National Politics in Trinidad and Tobago », paper presented to conference on challenges and change : «The Indian Diaspora in its Historical anal Contemporary contexts », The University of the West Indies, St. Augustine, Trinidad, 1995.

31. Tobago is one of the two islands in the twin-island state of Trinidad and Tobago. In terms of size, it constitutes less than one tenth of land area of the country as a whole and less than $5 \%$ of the population. In terms of local administration, Tobago operates under a Tobago House of Assembly, a different system from Trinidad, and with separate elections, and thus the 1996 local government election, in Trinidad, did not have any direct impact or relevance to Tobago. It is in this context that Tobago has not been given any indepth consideration in this paper. 


\section{SETTING THE STAGE FOR A 1996 LOCAL GOVERNMENT POLL}

Notwithstanding that the Parliamentary elections were contested on 6 november 1995, there was still the legal requirement for new government to call the local government elections within three months of 27 september 1995, the date on which all the councils retired, or to seek Parliamentary approval to defer the election. With the new government needing time to settle itself into government, as well as to attend to other «more pressing » constitutional matters, such as the Opening of Parliament and the delivery of the 1996 budget, it was inevitable that the government would seek Parliamentary approval to defer the election. Thus, early in december, a Bill was taken to the Parliament to restore the former local government councils for a maximum period of nine months, from 27 september 1995. While the Bill sought to extend the deadline for the holding of the elections until june 1996, the Minister did assure Parliament that the elections would be held «as soon as practically possible ${ }^{32}$. The extension was obtained though the former councils were not resuscitated, but rather were replaced by Advisory Committees ${ }^{33}$.

Although the Minister of Local Government had promised that the local government elections would be held « as soon as practically possible », the UNC-NAR government was in no rush to call the elections. Once the six-month extension was granted, the government diverted its attention to consolidating itself in office, while attempting to treat with various crises which either arose or were created by the largely inexperienced administration. In this regard, the government's first task was getting the 1996 budget passed before the end of January, as was constitutionally required. In so doing, the UNC-NAR revisited various plans of the former administration, and took the decision to discontinue various construction/developmental projects which were

32. See «Local Government Election on the Horizon », in Trinidad Guardian, December 9, 1995, p. 6.

33. See Trinidad and Tobago Parliament, « Act 36 of $1995 »$; also see K. Maharaj \& S. Sheppard, «Local Government Bodies Denied Extra Time », in Daily Express (Trinidad), December 16, 1995, p. 7. 
centralized in Port of Spain and environs. The Port of Spain Urban Renewal and Beautification programme as well as the National Library Complex, were deprioritised within the new government's budget. Such policy decisions were immediately politicized, both on the basis of race and political demography. From the political space perspective, having had the locus of power shifting «from Port to Plantation », there was the fear that the resources of the state would see similar shifts, resulting in the lack of any development to areas such as Port of Spain, and the urban east-west corridor, which in the main, supported and returned PNM representatives. Given the spatial distribution of race, such a scenario would mean that the Afro-Trinidadian community would be deprived of all the jobs which were to emanate from these projects. Furthermore, by inference, since development projects would be opened in central and south Trinidad, Indo-Trinidadians, who populate such areas, would have the advantage of finding employment there.

The employment concerns of Afro-Trinidadians were not just limited to construction workers. In the category of professionals, and even public sector workers, there were serious concerns as to whether Afro-Trinidadians were to be made to suffer as a form of direct retribution for the failure of that community to support the UNC. Such concerns erupted with the early termination of the contracts of several Afro-Trinidadians who were hired by previous governments to serve as Chief Executive Officers in various state enterprises A near similar situation arose at the Ministry of Education where the Minister reportedly sent his two Atro-Trinidadian Permanent Secretaries on vacation. Since ministers do not have any direct authority or control over public servants ${ }^{34}$, the position taken by Minister Nanan was quickly interpreted as having political and racial connotations. Consequently, the leader of the Opposition, in his contribution to the budget debate, and although not explicitly posing the question in terms of race, raised the question of public sector layoffs ${ }^{35}$. Consequently, in

34. See F. Joseph, «Lalla: Nanan wrong "Minister can send no officer on leave" », in Trinidad Guardian, January 3, 1996, p. 1.

35. See « Manning raises prospect of public sector layoffs », in Trinidad Guardian, January 17, 1996, p. 14. 
such a situation, the government, in recognizing possible civil problems, focussed its attention on dealing with some of the concerns of the Urban Afro-Trinidadian communities. The Prime Minister and his Ministers visited several communities, in the PNM heartland of Laventille and Sea Lots ${ }^{36}$, in the hope to minimize any fears that the Afro-Trinidadian community may have of an «Indo-Trinidadian government». But whereas some of these concerns and even fears could be explained in terms of the plural society and the need to assuage the fears of ethnic domination ${ }^{37}$, the Panday administration created various crises of its own, which saw the diversion of attention and energies away from calling the local government election as « soon as was practically possible ». In this regard, a major debate in relation to the role of the media developed. The government went on the offensive, calling for a private newspaper to dismiss its editor, after the newspaper carried certain stories and pictures which seemingly misrepresented the Prime Minister. While the Prime Minister may not have obtained the dismissal of the editor, the debate which raged, and which was fueled by other internal disagreements and developments in the media industry saw the diversion of attention from everything else, including the local government poll. Effectively, this allowed the UNC-NAR two additional months before focussing attention on a local government poll. Accordingly, with the five months passing between the time the government went to Parliament to get an extension for the calling of the election, the Prime Minister announced, in may, that the local government poll would be contested on 24 june 1996, a mere three days before the expiration of the extension granted by the Parliament.

36. See R. Lord, «Panday : I'm no Caroni PM », in Trinidad Guardian, March 28, 1996, p. 1.

37. See R. R. Premdas, «The Anatomy of Ethnic Conflict: Domination Versus Reconciliation », in Ralph Premdas ed., The Enigma of Ethnicity, Trinidad, School of Continuing Studies, 1993. 


\section{RACE AND TIDE CAMPAIGN IN TIIE 1996 LOCAL GOVERNMENT ELECTION}

Although the legislative requirements dictated that the local government poll was to be conducted before 27 june 1996, all the parties, including the ruling coalition, which had the power of determining the date of the poll, were not prepared when the date was finally announced. This was clearly demonstrated by the rush of all parties to find candidates and to draw up their official manifestos for the poll. With reference to the manifestos, all three parties sought to lay a framework based on a local government orientation. In this regard, all three parties adopted a near similar philosophical approach to local government. They all spoke of the need to foster community participation in local government. Thus, for instance, the UNC titled its manifesto «Empowering the People». Based on the title, the manifesto sought to outline the need for a «partnership with the people » to be developed with local government authorities. The UNC's partner in the coalition, the NAR, also called for greater participatory democracy. In its manifesto entitled «Empower your Community: Building from the Ground Up », the NAR complained about the emasculation of local government, and thus posited the urgent need to resuscitate local government. In line with such a position, the PNM, too, proposed to build communities through community participation.

Beyond the philosophical underpinnings of local government, the manifestos explored the future and functioning of local governments. There was the call for further decentralization in terms of devolving additional powers and functions to local government. In this regard, the PNM and UNC manifestos focussed on management and staffing considerations, with both proposing to ensure adequate staff and resources to ensure that the local government councils deliver the services for which they were responsible.

Having outlined very broad perspectives, the manifestos were silent on the specifics of making all of this happen. Consequently, it was anticipated that on the campaign trail, some of those specific details would be outlined. However, this was not to happen. The only 
major local government issue which was discussed on the campaign was the move by the government to proclaim the Municipal Corporations Act a week before polling day. The UNC boasted that it had succeeded in proclaiming the Act in its entirety following only eight months in office, while the PNM had failed to do so during the previous four years. The PNM countered by suggesting that, even though the UNC did proclaim the Act, the mechanisms to enforce the sections now proclaimed were not in place and thus any such proclamations would be rendered useless. But apart from this subject, no other local government issue received any substantive treatment on the campaign trail beyond what was stated in the manifestos. On the hustings, national issues predominated.

With the local government election having been called in the shadow of the parliamentary election, as well as in light of the various national debates and concerns, it was inevitable that the campaign was to locus on such national issues rather than local ones. Consequently, when the parties had finalized their slate of candidates and thus began, in earnest, the campaign, the issues were national rather than local. The Opposition PNM called its manifesto «Enough is Enough», and considered the june 1996 polls a referendum on the UNC-NAR coalition government ${ }^{38}$. The UNC, which fought the election in an accommodation with its coalition partner in central government, accepted the PNM's challenge that the election should be viewed as a referendum on the government's eight month reign. Thus, in winding down his campaign, Prime Minister Panday asked his supporters for their vote as a sign of saying «Yes, you're going right ${ }^{39}$. The third party in the race, the NAR, while seemingly trying to explicitly steer away from national issues, ended up in doing just that. The NAR focused its attention on the issue of national unity, and thus campaigned on the basis that it was the only organization which could bridge the gap between the two ethnic groups. At the same time, the NAR's campaign took on a more partisan perspective, whereby party

38. See «Enough is Enough' Manning : june 24 polls referendum on Govt », in Sunday Guardian, June 2, 1996, p. 1.

39. See « Panday asks voters for the sign », in Sunday Express, June 23, 1996, p. 3. 
leaders suggested that the party's success in the local government elections, would serve to empower the NAR within the coalition government $^{40}$. The campaign, therefore, at least from the perspective of what was to be presented on the platforms of the three political parties, focussed on national rather than local government issues.

On the hustings, with the election being viewed as a referendums, the UNC and NAR concentrated on defending the policies adopted within the preceding seven months. The UNC, claiming that «we've only just begun », identified various policies related to reducing prices of food and other consumer goods, the fight against crime, as well as a review of energy sector policies which were to result in increased earnings from that sector. In full page newspaper advertisements, the UNC reminded the population of the previous Manning's administration record, suggesting PNM's mismanagement of the economy, resulting in widespread poverty. Fingers were also pointed at the PNM in the disposal of state enterprises, in a manner not beneficial to the state.

In turn, the PNM campaign, with regard to the national issues, focussed on the failure of the government to bring about a substantial reduction in the high crime rate and in the cost of living, arguing that the UNC had failed on both these counts. The PNM platform speakers questioned the government's policy on national unity. Instead of national unity, the PNM alleged that the government was promoting disunity, and this was manifested in terms of victimization, unfair dismissals, as well as the forgiving of a debt to Guyana ${ }^{41}$. Most of theses issues, reflected the centralization of the racial factor in Trinidad's politics. While all the parties in the campaign claimed not to have resorted to the race card, they all raised the issue of race in the various campaign speeches. The PNM implicitly warned its supporters

40. See Peter Richards, «ANR : Win will help NAR to reorganize », in Trinidad Guardian, June 10, 1996, p. 1.

41. The issue of debt forgiveness to Guyana, was viewed in a racial context, whereupon it was an «Indo-Trinidadian » government helping an «Indo-Guyanese government». See Suzanne Mills, «PNM jury' delivers guilty verdict on coalition Govt », in Newsday (Trinidad), June 16, 1996, p. 2. 
of racial discrimination by the UNC-NAR government. At the launching of the campaign, PNM leader, Patrick Manning, spoke of discrimination, making specific reference to employment of AfroTrinidadians. Without explicitly referring to race, Manning complained about «discrimination and division». He argued that under his administration, four administrative regions along the east-west corridor, which coincidentally were predominantly populated by AfroTrinidadians, had comparatively higher levels of poverty than County Caroni, a predominantly Indo-Trinidadian region. Accordingly, in 1995, his administration created over 200 unemployment relief projects (URP) in the East-West corridor, while 16 such projects were implemented in County Caroni. Manning complained that in 1996, the UNC-NAR government had decreased the number of projects in the east-west corridor to 129 , while it increased County Caroni's tally to $36^{42}$. This was presented as an indicator of government's « discriminatory practice » against PNM strongholds.

Following his initial salvo, Manning persisted with the concerns of discrimination, and in making reference to the firing of Chief Executive Officers of various state enterprises, ensured that such dismissals were an election issue. In this regard, Manning was later to say, on a public platform, that the UNC-NAR government, « under the disguise of national unity they are imposing on this population some of the most racist acts ever perpetrated by any government of Trinidad and Tobago ${ }^{43}$. The PNM thus brought the issue of race home to the election.

While the PNM attacked the governing coalition for racial discrimination, both coalition partners argued that their parties were rather seeking to promote national unity. In this regard, the NAR party chairman told a public meeting that the « future of national unity

42. Sandra Chouthi, «Manning sees Govt Caroni bias », in Sunday Express (Trinidad), June 2, 1996, p. 1.

43. Stephen Boodram, «Manning : Racist acts under national unity », in Trinidad Guardian, June 10, 1996, p. 1. 44. See «NAR : Victory will make us equal », in Trinidad Guardian, June 19, 1996, p. 545. Debra Wanser, «The PNM is now like the DLP », in Sunday Guardian (Trinidad), June 23, 1996, p. 17. 
in this country lies with the NAR in conjunction with the UNC ${ }^{44}$. Accordingly, when national unity is viewed as racial harmony, the NAR's position was simply that the PNM was unable to bridge the gap amongst the various ethnic groups of the society.

The UNC, in adopting a somewhat similar position, sought to chastise the PNM for focussing on race, and in appealing « to only one race ». UNC leader Panday thus likened the PNM to the Democratic Labour Party (DLP), which was the Indo-Trinidadian party of the 1960s. The DLP had failed to win an election because it appealed only to Indo-Trinidadians. Consequently, Panday advised that «no party can become the Government unless it can appeal to both Indians and Africans ${ }^{45}$. On this basis the UNC defended its position and policies, claiming that the PNM's claim of racist acts were simply last ditch efforts to win support. Panday further claimed that all the issues raised on the PNM platform had racial overtones. He declared that the PNM's attacks on Caroni, as well as the PNM's campaign against the dismissals of certain CEOs were placed in a racial context. He even cited the debt forgiveness to Guyana, which arose out of a Paris Club formula, as having racial overtones. With regard to the debt forgiveness to Guyana, the Panday administration had argued that it was well accepted by the majority that it was impossible to recover all the Guyanese debt. His government was therefore moving to recover some of the debt, but, he added, the mere forgiveness was being postulated as a race-based decision, where the Trinidad «Indian government » was freeing a Guyanese «Indian government» of its debts. From this perspective, Panday claimed that his government was firm in its quest for national unity and would not divide the country on racial or any other grounds ${ }^{46}$.

44. See «NAR : Victory will make us equal», in Trinidad Guardian, June 19, 1996, p. 5 .

45. Debra Wanser, "The PNM is now like the DLP », in Sunday Guardian (Trinidad), June 23, 1996, p. 17.

46. Yvonne Webb, «Panday: we will not divide country on racial grounds », in Trinidad Guardian, June 6, 1996, p. 3. 
Having stage-managed their campaigns, so much so as to ensure that the apathetic in the society would be compelled to make their vote count, polling day was approached with great anticipation by all parties. The PNM hoped that the election result would show it was regaining ground lost in the Parliamentary election of November 1995. There was concern that the PNM had lost ground in the 1995 elections because it had failed to inspire some Afro-Trinidadians to vote for the party $^{47}$. For the PNM therefore, the 1996 election presented the opportunity to regain ground, by consolidating the Afro-Trinidadian vote for the PNM. The UNC, on the other hand, saw the poll as a mirror to reflect public opinion of its short tenure in office, and thus hoped for a vote of confidence. Again in terms of race, the UNC was hoping that such a vote of confidence could only be possible with support from both Afro and Indo-Trinidadians. The NAR conceived the election merely as rule of measure to legitimize the NAR's place in Trinidad's politics, inclusive of all the races, and not be confined to Tobago. In this context the results of the elections are now to be assessed.

\section{THE RESULT AND ITS IMPLICATIONS ON PARTY POLITICS IN TRINIDAD}

Although the platform campaigning by the three political parties was predominantly focussed on issues other than local government ones, the fact remains that the contest was for the control of fourteen municipal corporations which comprised, in total, 124 electoral districts. Of the 260 candidates who contested the election, 10 were identified as independent candidates ${ }^{48}$, while the other 250 contested

47. See Selwyn Ryan, «Round of applause for calypso », in Sunday Express, February 25, 1996, p. 9.

48. It may be noted here that the 10 independent candidates were originally screened and some were even selected as candidates for the UNC, prior to the announcement of the accommodation with the NAR. On the announcement that certain seats were allocated for the NAR to contest, the disgruntled aspiring UNC nominees proceeded to have themselves nominated as independent candidates. 
the poll on a party card, with 124 candidates standing for the PNM while another 126 representing the UNC-NAR accommodation ${ }^{49}$.

Notwithstanding the entry of the NAR in the elections, it was clear that its participation was to be limited, since it did not possess an electoral base in Trinidad, unlike the other parties, the PNM and UNC. More importantly, the bases of these latter parties were grounded in racial blocs. Such a perspective is further supported through an analysis of the historical evidence and how constituencies voted, and culminating in the electoral tie that emanated in the 1995 parliamentary election. In such a context therefore, the NAR chances of success in 1996 were remote because, based on its accommodation with the UNC, the seats allocated for the NAR to contest were strongholds of the PNM. Moreover, even in those instances where the PNM was not insurmountable, the NAR faced the challenge of «independent» candidates, who sought to divide the anti-PNM vote sufficiently for the PNM to retain the seats. A case in point was the Calvary district in the Arima Borough, where the PNM candidate, Melan Garcia, secured only 484 votes while the «independent», Martin Hollingsworth, received 417, with 252 votes going to Peter Asse, the NAR candidate. Effectively, the NAR was later to complain that the UNC undermined their candidates' chances of victory by giving « critical » support to the «independents» who were really the UNC's candidates for the election, but who had not contested on a UNC ticket because of the accommodation. Notwithstanding such evidence, the fact remains that the NAR, as well as all the independent candidates failed to win any of the 124 available seats.

Without any success for the NAR or the independents, the seats in the 1996 local government election were shared by the PNM and the UNC. The PNM won 63 of the 124 seats with the UNC taking the

49. In the week preceding nomination day, an accommodation was reached between the UNC and the NAR, whereupon it was decided that the UNC was to contest 90 seats with the other 34 being contested by NAR candidates. However, at nomination day, two persons who were screened and proposed by their respective parties before the accommodation was finalized, proceeded to file nomination papers on behalf of their respective parties. Effectively with these two additional candidates, the 250 persons represented contested the election on a party card. 
other 61. But, whereas in terms of numbers, the PNM won more than half of the available seats, a more detailed analysis of the results, especially in terms of comparative analysis between the 1992 and 1996 polls, show the PNM as having lost substantive ground, in the realm of local government, while at the same time the UNC seemed to be in the ascendancy.

Although the PNM won the majority of seats in 1996, that majority was significantly reduced from what the party had obtained in 1992. Put differently with the PNM having won 63 of the 124 seats in 1996 , its proportion of seats in the local government arena was reduced from 62 percent, in 1992, to 51 percent in 1996. This 11 percent decline in the PNM's proportion was transferred to the UNC, which saw its proportion of seats rise from 38 percent to 49 percent over two elections. A similar scenario occurred in relation to the votes cast. In the 24 june 1996 local government poll, the UNC obtained 178800 votes as compared with the PNM's tally of 154307 . The UNC obtained 24000 more votes that the PNM in 1996. Since 1956, when the PNM entered party politics in Trinidad, this was the first time that the PNM, as a party, received less votes than any other party in a local government poll. Furthermore, and from the comparative perspective of the 1992 and 1996 local government polls, despite an increase in the electorate of over 24 000, the PNM's 1996 tally of votes was slightly lower (511) than what the party had received in the 1992 local government poll. A near opposite picture emerges for the UNC, which saw an increase of over 65000 votes from what that party polled in 1992.

Apart from actual votes, the UNC, in 1996, has been able to advance its challenge in breaking the PNM's hegemony on local government. From the perspective of control of the municipal corporations ; this result ensured that the PNM obtained the majority of seats in seven of the fourteen councils, with the UNC having a majority in another six. One council, the Siparia Regional Corporation, which had eight electoral districts, was split four seats each for the PNM and the UNC. This tie, was later broken by the «drawing of lots » and resulted in the UNC gaining control of the council. Consequently, control of the fourteen corporations are now equally shared by the UNC and the PNM. 
The equal sharing, in 1996, of the fourteen municipal corporations between the PNM and the UNC serves to underscore the electoral tie which resulted in the 1995 Parliamentary election. But more importantly, the electoral map which demonstrates political party distribution of parliamentary seats is, with minor adjustments, near replicated by the map showing party controls of the various local government councils. Put differently, the results of the 1996 local government poll clearly emphasizes the political configuration and division of Trinidad, between the UNC and the PNM. Moreover, when such a party-based configuration is contrasted with the racial demography, it becomes easily visible that the politics and voting behavior of citizens in Trinidad is closely linked with race. Effectively therefore, the result of the 1996 local government poll serves to emphasize that racial voting divides Trinidad today, and moreover, that party consolidation is closely tied to race-based politics, the concern is whether a local government can really facilitate local participation in government or if, in the Trinidad context, all a local government poll serves to do is to consolidate race-based parties.

\section{CONCLUSION}

The 1996 local government poll clearly emphasized the racebased political party structure in Trinidad as was indicated earlier in the 1995 Parliamentary elections. However, in positing that race is a critical consideration in determining party consolidation and support and, by extension, who governs, the more important question which faces the society is that in acknowledging the near, equality between Afro- and Indo-Trinidadians, is the polity condemned to political stalemate? Moreover, in such a context, what scope is there for political stability? While this paper does not propose to offer substantive answers to such questions, certain lessons can be gleaned from the present political scenario.

With the near equality of the two dominant races in Trinidad, and with the two major race-based parties drawing their support from their respective racial bloc, both parties must seek to promote the interest of all the differing groups and blocs of the society if they are to 
enhance their chances of electoral success. Put differently, the PNM seems to have been on the decline, if only because there seemingly is the alienation of Indo-Trinidadians from the party. The emphasis, by the PNM leadership, on perceived racial-discrimination of the AfroTrinidadian community by an Indo-Trinidadian government, as well as the sustained attacks on the supposedly well being of County Caroni, the heartland of the Indo-Trinidadian community, served to push IndoTrinidadians into the belief that the PNM did not care about them. Indo-Trinidadians thus grabbed at the opportunity to galvanize themselves around the UNC, the «Indian Party » which would have to protect their interest. Such a perspective was further compounded by comments from politicians and political analysts that there was an urgent need to restrict the ascendancy of the Indo-Trinidadians, who had achieved government. In this regard, on the night of the elections, one commentator clearly stated that the Afro-Trinidadian community must band together, if only to put a halt to the continued rise of the Indo-Trinidadians ${ }^{50}$. Such statements have only served to further concretize and consolidate the Indo-Trinidadian community into one bloc, since what was seemingly being portrayed was that political power did not rightfully belong to the Indo-Trinidadians. In such a scenario, Indo-Trinidadians have been forced onto the defensive and thus it is highly likely that they will continue to vote race, until such a time that they are fully accepted as equals and not as minorities or second class citizens.

Of course, at the same time, the UNC, as well as the PNM must strive to become mass-based parties. To this end, both parties must seek to win the support of the citizens of mixed ancestry, as well as those of European, Chinese and Syrian-Lebanese descent. Since these communities comprise 15 percent of the electorate, they could seemingly serve as a good tie-breaker in an election based on party politics with a racial configuration.

50. Lloyd Best, an Afro-Trinidadian commentator stated on national television that the pendulum which had swung too far, and as such all Airo-Trinidadian political parties must combine forces to ensure that there is a check on the rise of IndoTrinidadians to political power. 


\section{Résumé}

Bien que les manifestes des trois partis politiques en lice lors des élections du gouvernement local de Trinidad en 1996, aient suggéré que les élections concernaient surtout des questions locales gouvernementales, il n'en demeure pas moins vrai que les problèmes d'ethnicité, de race et de communalisme ont réellement bouleversé la campagne, dans la course aux élections. Nonobstant le fait que les manifestes étaient centrés sur l'absence presque totale de décentralisation du pouvoir et de l'autorité aux organismes gouvernementaux locaux, les préoccupations d'autonomie locale et le manque d'efficacité du système gouvernemental local, la véritable campagne semble avoir voué ces considérations à un rang auxiliaire dans le contexte électoral. Bien sûr, un tel scénario s'explique par le fait que les élections de 1996 du Gouvernement local se sont déroulées dans l'ombre des élections parlementaires de 1996 et ont, de ce fait, redynamisé les partis politiques autant que ranimé les divisions raciales et même les tensions de la société trinidadienne. Les élections ont effectivement contribué à restructurer et à consolider les blocs raciaux et politiques existants sur la scène trinidadienne.

\section{Abstract}

Whereas the manifestos of the three political parties which contested the 1996 local government elections, in Trinidad, suggested that the elections were really about local government issues, the fact remains that issues of ethnicity, race and communalism served to overwhelm the actual campaigning in the run up to the elections. Notwithstanding that the manifestos focussed on the near lack of devolution of power and authority to the local government corporations, the concerns of local autonomy, and the lack of effectiveness of local government system, the actual campaign seemed to have destined these considerations to being ancillary issues within the context of the elections. Of course such a scenario is explained by the fact that the 1996 local government election came in the shadow of the 1996 Parliamentary elections, and as such had the effect of re-energizing party politics as well as racial divisions and even tensions in the Trinidad society. Effectively, the elections served to streamline and consolidate the political and racial blocs which exist in the Trinidad setting.

\section{Mots-clés}

Communalisme - Démocratie Elections - Ethnicité et race Gouvernement local - Partis politiques Trinidad 